\title{
PENGGUNAAN ISTILAH BERBAHASA ARAB PADA KOMUNITAS PERGERAKAN ISLAM DI KOTA SEMARANG: TINJAUAN SOSIOPRAGMATIK
}

\author{
Retno Purnama Irawati ${ }^{1}$
}

\begin{abstract}
The Arabic terms usage problems in Islamic Movement Community are interested to be explored by the researchers because the linguistic situation in Islamic Movement Community is enough unique if it is compared with the linguistic situation in another social community. It is necessary to be explored by deep doing about the linguistic behavior that is related to registers and speech acts, the linguistic interaction patterns in what context, to whom, when, what for and where, which them to be done by spoken. The main problems in this study are register and speech act in Arabic terms applied in Islamic Movement Community and their motivation in employing Arabic terms in doing communication in Islamic Movement Community. There were some registers and speech acts in Arabic terms applied in Islamic Movement Community found as follows: locution speech act, illocution speech act, representative speech act, comissive speech act, directive speech act. Expressive and declarative speech act were not found in their speech act. To get data about their motivation and Arabic terms applied context in doing communication in Islamic Movement Community used questionnaire. There were 150 questionnaires given to respondents and 95 questionnaire that could be taken.
\end{abstract}

Keywords: Register and Speech Act, Aociopragmatics.

\section{A. PENDAhUluan}

Bahasa merupakan alat komunikasi manusia yang paling vital. Komunikasi melalui bahasa merupakan salah satu perwujudan ekspresi diri manusia. Keraf berpendapat bahwa komunikasi merupakan akibat yang lebih jauh dari ekspresi diri. Sebagai alat komunikasi, bahasa merupakan saluran-saluran perumusan maksud kita, melahirkan perasaan kita dan memungkinkan kita menciptakan kerja sama dengan sesama warga. Komunikasi mengatur aktifitas kemasyarakatan, merencanakan dan mengarahkan masa depan kita. Komunikasi juga memungkinkan manusia menganalisis masa lampaunya untuk memetik hasil-hasil yang berguna bagi masa kini dan masa yang akan datang (Keraf, 1994 : 4).

Dick menyimpulkan bahwa komunikasi sebagai fungsi yang paling umum bagi pemakai bahasa. Bahasa bukan semata-mata terjadi melalui pemakai bahasa tetapi juga terdapat bentuk komunikasi non verbal. Bahasa juga sebagai sarana yang paling terperinci dan efektif untuk dapat berkomunikasi dengan orang lain (Dick, 1994 : 20-21). Agar terjadi komunikasi yang bermakna, pembicara dan pendengar perlu adanya pengenalan. Untuk itu

\footnotetext{
${ }^{1}$ Penulis adalah Dosen Prodi Bahasa Arab Jurusan BSA FBS UNNES.
} 
dituntut untuk mengenal sistematika bahasa dan pemakaian bahasa yang digunakan oleh pembicara.

Koentjaraningrat dalam Chaer mengatakan bahwa kebahasaan berada di bawah kebudayaan (Abdul Chaer, 1990 : 12). Dengan kata lain bahasa merupakan salah satu unsur, subsistem dari unsur-unsur lain di dalam kebudayaan. Bahasa mempengaruhi kebudayaan dan cara berpikir sehingga ciri-ciri bahasa itu akan tercermin pada sikap dan budaya manusia penuturnya. Banyak orang mempunyai kemampuan berbahasa, dalam kemampuan berbahasa itu kebanyakan budaya di dunia menambahkan di kalangan anggota-anggota tertentu suatu kesadaran terhadap bahasa ini mungkin pertama-tama dirangsang oleh hubungan dengan penutur bahasa asing, oleh keberadaan dan pengakuan terhadap pemisahan dialek dalam suatu masyarakat tutur, atau oleh suatu kecenderungan bawaan manusia yang tidak ingin tahu tentang dirinya sendiri dan dunia sekitarnya (Robin, $1995: 1$ ).

Perwujudan verbal dari kemampuan berbahasa manusia dalam komunikasi adalah dalam bentuk perilaku berbahasa. Perilaku berbahasa merupakan sikap mental seseorang dalam memilih dan menggunakan bahasa dalam berbagai situasi. Perilaku berbahasa berhubungan erat dengan dinamisnya masyarakat bahasa dalam berbagai kegiatan dan kelompok. Perilaku berbahasa ini memunculkan berbagai keanekaragaman penggunaan bahasa.

Keanekaragaman penggunaan bahasa jelas nampak saat anggota dalam komunitas pergerakan Islam KAMMI dan unit-unit kerohanian Islam kampus di kota Semarang berkomunikasi baik lisan maupun tulisan di lingkungan kegiatan pergerakan, di luar kegiatan pergerakan, dan di lingkungan tempat tinggal atau asrama mereka sendiri. Bahasa-bahasa tersebut mereka gunakan saat berinteraksi dengan lawan bicara dengan memperhatikan situasi dan kondisi tertentu. Para anggota dalam komunitas pergerakan Islam tersebut menggunakan bahasa lisan saat berinteraksi dengan teman sesama komunitas pergerakan Islam, teman di luar komunitas pergerakan Islam, dan masyarakat. Bahasa lisan tersebut sebagian besar merupakan bahasa Indonesia dengan banyak mempergunakan istilah-istilah berbahasa Arab.

Penggunaan istilah-istilah berbahasa Arab dalam komunikasi berbahasa Indonesia membuat bahasa Indonesia semakin berkembang. Hal ini terjadi karena adanya kontak bahasa Indonesia dengan bahasa-bahasa lain, termasuk bahasa Arab. Adanya kontak bahasa yang terjadi pada bahasa Indonesia menjadikan kosakata bahasa Indonesia semakin berkembang. Menurut Soedjito (1992) sumber perluasan kosakata itu pada dasarnya ada dua macam, yaitu (1) sumber dalam adanya swadaya bahasa Indonesia itu sendiri yang berwujud pengaktifan kata-kata lama, pembentukan kata-kata baru, penciptaan, dan pengakroniman, (2) sumber luar adalah perluasan kosakata yang diambil dari bahasa daerah dan bahasa asing yang disebut dengan kata-kata pungutan/pinjaman.

Penggunaan istilah-istilah berbahasa Arab pada komunitas pergerakan Islam di kota Semarang ini merupakan contoh adanya kontak bahasa Indonesia dengan bahasa Arab. Kesetiaan anggota komunitas mempergunakan istilah-istilah berbahasa Arab dimotivasi oleh keinginan mereka untuk menunjukkan identitas sebagai seorang Muslim. Di sisi lain, penggunaan istilah-istilah berbahasa Arab tersebut mengalami perluasan makna dari makna asalnya dalam bahasa Arab. Sebagai contohnya adalah penggunaan istilah liqo' yang bermakna perjumpaan. Istilah liqo' mengalami perluasan makna menjadi pertemuan untuk melangsungkan rapat dan berdiskusi. Istilah lain adalah antum yang bermakna Anda (lakilaki yang berjumlah lebih dari satu). Istilah antum mengalami penyempitan makna menjadi 
penyebutan untuk menggantikan kata Anda (baik bagi laki-laki maupun perempuan), dengan tujuan untuk memberi penghormatan. Contoh lain adalah istilah syuro yang bermakna bercurah pendapat. Istilah syuro mengalami perluasan makna menjadi rapat atau pertemuan yang sifatnya besar dan massal.

Masalah penggunaan istilah-istilah berbahasa Arab pada komunitas pergerakan Islam ini merupakan hal yang menarik bagi peneliti karena situasi kebahasaan pada komunitas pergerakan Islam yang cukup unik jika dibandingkan dengan situasi kebahasaan di kelompok sosial masyarakat yang lain. Keadaan demikian mendorong peneliti untuk melakukan penelitian ragam dan tindak tutur penggunaan istilah berbahasa Arab pada komunitas pergerakan Islam, pola perubahan makna istilah berbahasa Arab, dan motivasi penggunaan istilah berbahasa Arab dalam berkomunikasi pada komunitas pergerakan Islam, sehingga terjadi pilihan bahasa dalam kehidupan sehari-hari dengan pemakaian yang tinggi dan penguasaan yang maksimal. Selain itu, peneliti merasa perlu untuk melakukan penelitian lebih jauh tentang perilaku berbahasa yang berkaitan dengan ragam dan tindak tutur, pola interaksi berbahasa dalam konteks apa, kepada siapa, kapan, untuk apa dan di mana, yang semuanya dilakukan secara lisan.

Rumusan masalah yang dibahas dalam penelitian ini adalah ragam dan tindak tutur penggunaan istilah berbahasa Arab pada komunitas pergerakan Islam dan motivasi penggunaan istilah berbahasa Arab dalam berkomunikasi pada komunitas pergerakan Islam. Penelitian ini merupakan penelitian kualitatif yang menggunakan metode identifikasi. Sifat kualitatif penelitian ini mengarah pada pembahasan permasalahan tentang ragam dan tindak tutur penggunaan istilah berbahasa Arab, pola perubahan makna istilah berbahasa Arab, dan motivasi serta konteks penggunaan istilah berbahasa Arab dalam berkomunikasi pada komunitas pergerakan Islam. Kemudian dalam upaya memecahkan masalah penelitian ini, ada tiga tahapan yang dilakukan, yaitu 1) penyediaan data, 2) penganalisaan data dan, 3) penyajian hasil analisa data.

Sasaran penelitian ini dipilih secara acak dengan pertimbangan subjek adalah komunitas pergerakan Islam di kota Semarang. Pergerakan Islam pada penelitian ini adalah organisasi KAMMI dan unit-unit kerohanian Islam kampus. Selain itu, subjek penelitian berstatus aktif sebagai anggota ataupun aktivis pergerakan Islam KAMMI dan unit-unit kerohanian Islam kampus, serta tanpa membedakan jenis kelamin.

\section{B. PEMbahaSAN}

Responden penelitian ini mahasiswa yang ikut dalam kegiatan organisasi Islam kampus dan sedang aktif kuliah di universitas-universitas di kota Semarang. Responden yang memberikan respon terhadap angket yang telah disebar sebanyak 95 orang. Teknik pengumpulan data dilakukan dengan melakukan observasi partisipatif untuk mendapatkan data tentang ragam dan tindak tutur penggunaan istilah berbahasa Arab pada komunitas pergerakan Islam, kemudian peneliti meminta masing-masing responden mengisi angket yang telah dipersiapkan. Adapun hasil analisis data adalah sebagai berikut.

\section{Ragam dan Tindak Tutur Penggunaan Istilah Berbahasa Arab pada Komunitas Pergerakan Islam}

Percakapan sebagai peristiwa tutur merangkum tindakan yang beragam sesuai dengan situasi tertentu. Tindak tutur merupakan hal yang penting dalam kajian pragmatik, mengujarkan sebuah ujaran tertentu dapat dipandang sebagai suatu tindakan (mempengaruhi, menyuruh) di samping mengucapkan atau mengujarkan tuturan itu 
(Rustono, 1999 : 31). Tindak tutur atau tindak ujar (speech act) adalah aktifitas mengujarkan atau menuturkan tuturan dengan maksud tertentu. Leech berpendapat bahwa sebuah tindak tutur hendaknya mempertimbangkan lima aspek situasi tutur yang mencakupi (1) penyapa dan pesapa, (2) konteks tuturan, (3) tujuan tuturan, (4) tuturan sebagai bentuk tindakan atau kegiatan dan (5) tuturan sebagai bentuk produk verbal. Ada bermacam-macam tidak tutur yang digunakan penutur dalam berkomunikasi dengan bahasa melalui kegiatan percakapan (Leech, 1983 : 13).

\section{a. Tindak Tutur Lokusi (Lokuitionary Act)}

Berkenaan dengan ujaran menurut Austin dalam Leech (1983 : 316), ada tiga jenis tindakan yakni tindak lokusi (lokuitionary act), tindak ilokusi (ilokuitionary act), dan tindak perlokusi (perlokuitionary act). Tindak tutur lokusi adalah tindak tutur yang menyatakan sesuatu dalam arti "berkata" atau tindak tutur dalam bentuk kalimat yang bermakna dan dapat dipahami. Tindak lokusi adalah tindak tutur yang dimaksudkan untuk menyatakan sesuatu. Lokusi semata-mata merupakan tindak tutur atau tindak bertutur, yaitu tindak mengucapkan suatu dengan kata dan makna kalimat sesuai dengan makna itu (di dalam kamus) dan makna kalimat itu menurut kaidah sintaksisnya. Tindak lokusi tidak mempermasalahkan maksud fungsi ujaran (Rustono, 1999 : 35).

Konteks-konteks pembicaraan pada penelitian ini yang termasuk dalam tindak tutur lokusi adalah sebagai berikut.

Konteks 1. Peristiwa tutur antara seorang aktivis rohis dengan teman sesama aktivis rohis mengenai agenda rapat tertentu.

A : Bagaimana baiknya ya apakah kita harus melakukan syuro' dulu? Apa murobbi harus diundang juga?

B : Syuro' itu penting dilakukan dan didiskusikan dengan para murobbi untuk agenda yang mendesak.

Syuro' pada konteks pembicaraan tersebut bermakna 'rapat atau pertemuan untuk membahas sesuatu'. Murabbi mempunyai makna seorang pembimbing atau penasehat. Murabbi di kalangan aktivis rohis tidak hanya berperan sebagai pembimbing atau penasehat khusus saja, melainkan juga bisa bertindak sebagai perantara saat seorang anggota bimbingannya akan melakukan penjajakan dan perkenalan untuk menikah.

Konteks 2. Peristiwa tutur antara dua orang anggota pergerakan rohis yang sedang membicarakan seorang yang dikenal kepada teman yang lain.

A : Ane punya teman yang enak diajak diskusi karena luas banget wawasannya. Walaupun dia bukan ikhwan tapi dia hanif, loh.

B : Wah...boleh dong kapan-kapan ane juga dikenalkan ke temen antum itu ya.

Kata 'ane' pada konteks pembicaraan tersebut di atas, sebenarnya berasal dari kata 'ana' dalam bahasa Arab yang bermakna 'saya'. Kata 'ane' yang mengacu pada kata 'ana' sebenarnya terilhami oleh dialek Betawi, yang kemudian banyak dituturkan oleh orang-orang di luar penutur dialek Betawi. Kata 'antum' merupakan bentuk jamak dari kata ganti (dhamir) ' $a n t a '$ yang bermakna 'kamu (laki-laki)'. Kata 'antum' mempunyai makna 'kamu-kamu (laki-laki) sekalian'. Kata 'antum' pada konteks pembicaraan tersebut di atas bermakna 'kamu atau Anda', yang sengaja dipergunakan untuk maksud menghormati lawan tutur. 
Kata 'ikhwan' pada konteks pembicaraan tersebut di atas bermakna 'teman laki-laki yang beragama Islam' lebih khusus lagi merujuk pada teman laki-laki yang beragama Islam yang tekun beribadah dan mempunyai pandangan beragama yang sama dengan para aktivis rohis. Kata 'ikhwan' tersebut sebenarnya mempunyai makna asli yaitu 'saudara laki-laki'. Bisa jadi mereka mempunyai teman laki-laki yang beragama Islam tetapi tidak tekun dalam beribadah, maka tidak dalam kategori ikhwan menurut mereka. Kemudian kata 'hanif' dalam konteks tersebut mempunyai arti 'lurus'. Makna kata 'hanif' tersebut disepadankan dengan makna 'shalih' atau 'mempunyai kepribadian dan akhlak yang baik'.

Konteks 3. Tuturan seorang guru/ustadz sedang menyampaikan materi tentang keutamaan sabar.

A : Sebaik-baiknya kesabaran puncaknya adalah hilm. Maka selalu ana sampaikan dan ingatkan pada antum semua untuk selalu menjaga hilm meski sedang marah sekalipun. Semoga dalam majelis ini dapat menjadi sarana taskiyatun nafs bagi kita.

B : Insya Allah ustadz. Syukron.

Kata 'hilm' pada konteks pembicaraan di atas mempunyai makna 'kelembutan hati', padahal makna sebenarnya adalah 'mimpi'. Dan kalimat 'taskiyatun nafs' pada konteks pembicaraan di atas mempunyai makna 'pembersihan diri'. Istilah berbahasa Arab 'Insya Allah' biasa dipergunakan oleh pembicara saat menjanjikan sesuatu, sedangkan kata 'syukron' bermakna 'terima kasih'.

Konteks 4. Tuturan seorang guru/ustadz tentang muslimah dan urgensi bagi muslimah mempelajari ilmu.

A : Seorang akhwat itu harus bisa menjaga izzah-nya sebagai seorang muslimah. Seorang muslimah juga harus tekun mempelajari suatu bidang ilmu, makanya kita harus syumul dalam mempelajari suatu bidang ilmu. Salah satu pembelajaran yang efektif adalah melalui talakki yang berkelanjutan.

B : Insya Allah ustadzah. Syukron.

Kata 'akhwat' pada konteks pembicaraan di atas mempunyai makna 'saudara (perempuan)'. Kata 'izzah' dalam konteks pembicaraan di atas bermakna 'harga diri' padahal mempunyai makna yang sesungguhnya yaitu 'kejayaan'. Kata 'syumul' pada konteks pembicaraan di atas mempunyai makna 'sempurna' dan kata 'talakki' pada konteks pembicaraan di atas mempunyai makna 'pertemuan rutin'.

Konteks 5. Tuturan seorang aktivis pergerakan Islam yang menceritakan pengalamannya kepada teman sesama aktivis.

A : Kemarin ane baru silaturahim ke tempat umahat ...bahagia banget kelihatannya.

B : Wah, antum sudah kepengen ya $U k h \ldots$

Kata 'ane' pada konteks pembicaraan tersebut di atas, sebenarnya berasal dari kata 'ana' dalam bahasa Arab yang bermakna 'saya'. Kata 'ane' yang mengacu pada kata 'ana' sebenarnya terilhami oleh dialek Betawi, yang kemudian banyak dituturkan oleh orang-orang di luar penutur dialek Betawi. Kata 'antum' merupakan bentuk jamak dari kata ganti (dhamir) 'anta' yang bermakna 'kamu (laki-laki)'. Kata 'antum' mempunyai makna 'kamu-kamu (laki-laki) sekalian'. Kata 'antum' pada konteks pembicaraan tersebut di atas bermakna 'kamu atau Anda', yang sengaja 
dipergunakan untuk maksud menghormati lawan tutur. Kata 'umahat' mempunyai makna 'para ibu' tetapi dalam konteks pembicaraan di atas mempunyai makna 'seorang muslimah yang sudah menikah'. Kata ' $u k h$ ' di atas mengacu kepada kata ' $u k h t y$ ' yang bermakna 'saudaraku (perempuan)'.

\section{b. Tindak Tutur Ilokusi (Ilokuitionary Act)}

Tindak tutur ilokusi adalah tindak tutur yang biasanya diidentifikasikan dengan kalimat performatif yang eksplisit. Tindak tutur ilokusi ini biasanya berkenaan dengan pemberian ijin, mengucapkan terima kasih, menyuruh, menawarkan, dan menjanjikan (Chaer dan Agustina, 2004:53). Tindak tutur ilokusi adalah tindak melakukan sesuatu. Tindak tutur ilokusi merupakan tindak tutur yang mengandung maksud dan fungsi atau daya ujaran. Tindak ilokusi merupakan tindak tutur yang digunakan untuk menginformasikan sesuatu, tetapi juga melakukan sesuatu. Tindak tutur ilokusi mempertimbangkan siapa penutur dan siapa petutur, kapan, dimana tindak tutur itu terjadi, dan sebagainya.

Tindak tutur ilokusi tidak mudah diidentifikasi karena tindak tutur ilokusi berkaitan dengan siapa bertutur pada siapa dan kapan atau dimana tindak tutur itu dilakukan, dan sebagainya. Untuk memudahkan identifikasi ada beberapa verbal yang menandai tindak tutur ilokusi. Beberapa verba itu antara lain: melaporkan, mengumumkan, bertanya, menyarankan, berterima kasih, mengusulkan, mengakui, mengucapkan selamat, berjanji, mendesak, dan sebagainya. Adapun data-data tindak tutur pada penelitian ini yang termasuk dalam tindak tutur ilokusi adalah sebagai berikut.

(1) Jazakillah, Ukhty. Kuenya enak loh.

Tindak tutur tersebut diucapkan pada sebuah situasi ketika seseorang aktivis pergerakan Islam diberi hadiah berupa kue oleh teman yang lain. Frase 'jazakillah' mengandung makna 'ucapan terima kasih'. Kata 'ukhty' yang bermakna 'saudaraku (perempuan)'.

\section{(2) Tafadhol antum baiknya gimana? Nanti kita bawa usulan antum dalam forum syuro besar saja.}

Tindak tutur tersebut diucapkan pada sebuah situasi yang berlangsung di dalam sebuah rapat kecil, ketika seorang ketua rapat sedang menanggapi usulan dari rekan organisasinya. Kata 'tafadhol' bermakna 'dipersilahkan' tetapi pada kelompok aktivis bisa bermakna 'terserah'.

(3) Jangan lupa minggu depan dimuroja'ah lagi ya, hafalannya.

Tindak tutur tersebut diucapkan pada sebuah situasi ketika seorang guru yang menasihati muridnya setelah setor hafalan Al Qur'annya. Kata 'muroja'ah' bermakna 'belajar'. Belajar di sini bisa bermakna belajar apa saja. Tetapi dalam tindak tutur tersebut kata 'muroja'ah' bermakna 'mengulang hafalan Al Qur'an'.

(4) Kita harus waspada akan ghazwul fikr yang dibawa oleh kaum barat.

Tindak tutur tersebut diucapkan pada sebuah situasi formal dan informal saat membicarakan pengaruh globalisasi dari barat. Kata ' $g h a z w u l f i k r$ ' pada tindak tutur tersebut mempunyai makna 'perang pemikiran'. 
(5) Cari tempat syuro yang ada hijab-nya ya, Ukh.

Tindak tutur tersebut diucapkan pada sebuah situasi ketika seorang rekan meminta tolong pada yang lainnya. Kata 'syuro' pada tindak tutur tersebut mempunyai makna 'rapat, pertemuan'. Dan kata 'hijab' pada tindak tutur tersebut mempunyai makna 'penutup/penghalang' yang kemudian bisa dimaknai sebagai 'pembatas'. Sedangkan kata ' $u k h$ ' di atas mengacu kepada kata 'ukhty' yang bermakna 'saudaraku (perempuan)'.

(6) Silakan Pak mas'ul kalau mau menanggapi pendapat ane barusan.

Tindak tutur tersebut diucapkan pada sebuah situasi rapat oleh para aktivis, ketika seorang anggota yang mengharapkan komentar dari ketuanya terkait pembicaraannya. Kata 'mas'ul' pada tindak tutur tersebut bermakna 'ketua'. Kata 'ane' pada konteks pembicaraan tersebut di atas, sebenarnya berasal dari kata ' $a n a$ ' dalam bahasa Arab yang bermakna 'saya'. Kata 'ane' yang mengacu pada kata 'ana' sebenarnya terilhami oleh dialek Betawi, yang kemudian banyak dituturkan oleh orang-orang di luar penutur dialek Betawi.

(7) Ente ikut dauroh B kan, Akh?.

Tindak tutur tersebut diucapkan pada sebuah situasi ketika seorang teman bertanya pada teman yang lainnya. Kata 'dauroh' dalam tindak tutur tersebut mempunyai makna 'workshop/training/seminar/pelatihan'. Kata 'akh' mengacu pada kata 'akhi' yang bermakna 'saudaraku (laki-laki)'.

(8) Nanti yang baca tasmi' antum ya, Akh?'.

Tindak tutur tersebut diucapkan pada sebuah situasi seorang rekan meminta rekan yang lain untuk menyampaikan hafalan Qur'an-nya sebelum memulai rapat. Kata 'tasmi' mempunyai makna 'mendengarkan', tetapi dalam tindak tutur tersebut mempunyai makna 'mendengarkan bacaan Al Qur'an yang disampaikan orang lain'. Kata 'antum' mempunyai makna 'kamu-kamu (laki-laki) sekalian'. Kata 'antum' pada konteks pembicaraan tersebut di atas bermakna 'kamu atau Anda', yang sengaja dipergunakan untuk maksud menghormati lawan tutur. Dan kata ' $a k h$ ' mengacu pada kata 'akhi' yang bermakna 'saudaraku (laki-laki)'.

(9) Semoga dalam majelis ini dapat menjadi sarana taskiyatun nafs bagi kita.

Tindak tutur tersebut diucapkan pada sebuah situasi seorang guru/ustadz menyampaikan materi dalam majelis. Frase 'taskiyatun nafs' pada tindak tutur di atas mempunyai makna 'pembersihan diri'.

(10) Berkumpulnya kita disini semoga menjadi ghirah bagi masing-masing dari kita.

Tindak tutur tersebut diucapkan pada sebuah situasi seorang pemimpin acara sedang menyampaikan pembukaannya. Kata 'ghirah' pada tindak tutur tersebut mempunyai makna 'semangat'.

Anti aja ya, yang jadi idari-nya. 
Tindak tutur tersebut diucapkan pada sebuah situasi ketika seorang aktivis meminta tolong kepada teman sesama aktivis yang lain. Kata 'anti' dalam tindak tutur tersebut mempunyai makna 'kamu (perempuan)' yang memang sudah sesuai dengan makna asli dalam bahasa Arab. Dan kata 'idari' pada tindak tutur tersebut mengandung maksud 'sekretaris/ juru tulis'.

\section{(12) Kalau telat nanti di iqob lho, Ukh.}

Tindak tutur tersebut diucapkan pada sebuah situasi saat seorang teman mengingatkan teman yang lain. Kata 'iqob' pada tindak tutur tersebut mempunyai makna 'hukuman'. Dan kata ' $u k h$ ' di atas mengacu kepada kata 'ukhty' yang bermakna 'saudaraku (perempuan)'.

\section{(13) Besok kita riyadloh bareng, yuk!.}

Tindak tutur tersebut diucapkan pada sebuah situasi seorang teman sedang merencanakan acara bersama. Kata 'riyadloh' pada tindak tutur tersebut mempunyai makna 'olah raga'.

(14) Antum tsiqah gak kalo ane yang pegang kameranya?.

Tindak tutur tersebut diucapkan pada sebuah situasi seorang teman menanyakan keyakinan temannya terhadapnya. Kata 'antum' merupakan bentuk jamak dari kata ganti (dhamir) 'anta' yang bermakna 'kamu (laki-laki)'. Kata 'antum' mempunyai makna 'kamu-kamu (laki-laki) sekalian'. Kata 'antum' pada konteks pembicaraan tersebut di atas bermakna 'kamu atau Anda', yang sengaja dipergunakan untuk maksud menghormati lawan tutur. Kata 'tsiqah' pada tindak tutur tersebut bermakna 'percaya'. Dan kata 'ane' pada konteks pembicaraan tersebut di atas, sebenarnya berasal dari kata 'ana' dalam bahasa Arab yang bermakna 'saya'. Kata 'ane' yang mengacu pada kata 'ana' sebenarnya terilhami oleh dialek Betawi, yang kemudian banyak dituturkan oleh orang-orang di luar penutur dialek Betawi.

\section{(15) Ukhty, bisa minta tolong bantuin ane ngrekap data?.}

Tindak tutur tersebut diucapkan pada sebuah situasi seorang ikhwan sedang berbicara kepada seorang akhwat rekan kerjanya dalam organisasi. Kata 'ane' pada konteks pembicaraan tersebut di atas, sebenarnya berasal dari kata 'ana' dalam bahasa Arab yang bermakna 'saya'. Kata 'ane' yang mengacu pada kata 'ana' sebenarnya terilhami oleh dialek Betawi, yang kemudian banyak dituturkan oleh orang-orang di luar penutur dialek Betawi. Dan kata 'ukhty' yang bermakna 'saudaraku (perempuan)'.

\section{c. Tindak Tutur Representatif}

Adapun pembagian tindak tutur berdasarkan pengertiannya, dapat dikategorikan menjadi representatif, direktif, eksresif, komisif, dan deklarasi. Tindak tutur representatif disebut juga tindak tutur asertif, yakni tindak tutur yang mengikat penuturnya akan kebenaran apa yang diujarkannya (Rustono, 1999 : 38). Yang temasuk dalam jenis tindak tutur representatif ini seperti tuturan menyarankan, melaporkan, menunjukkan, membanggakan, mengeluh, menuntut, menjelaskan, menyatakan, mengemukakan, dan menyebabkan (Tarigan, 1990 : 47). 


\section{(1) Besok ada imtihan, materinya apa?.}

Tindak tutur tersebut diucapkan pada sebuah situasi ketika seorang aktivis memberikan informasi tertentu kepada temannya sesama aktivis. Kata 'imtihan' pada tindak tutur tersebut bermakna 'ujian'.

\section{(2) Ukhty fillaah, ada i'laan di dengarkan dulu.}

Tindak tutur tersebut diucapkan pada sebuah situasi ketika seorang aktivis menyarankan sesuatu kepada temannya. Frase 'ukhty fillaah' pada tindak tutur tersebut mempunyai maksud 'saudara seperjuangan di komunitas yang sama untuk menghormati'. Frase tersebut sebenarnya mempunyai makna 'saudara (perempuan) yang dalam lindungan Allah'. Sedangkan kata 'i'laan' mempunyai makna 'pengumuman'.

\section{(3) Kalau yang sirr itu jangan di jaherkan.}

Tindak tutur tersebut diucapkan pada sebuah situasi ketika seorang aktivis menyarankan sesuatu kepada temannya. Kata 'sirr' pada tindak tutur tersebut mempunyai makna 'rahasia' dan kata 'jaher' pada tindak tutur di atas mempunyai makna 'terbuka/jelas'.

\section{(4) Ada undangan amniah untuk antum.}

Tindak tutur tersebut diucapkan pada sebuah situasi ketika seorang aktivis menginformasikan sesuatu kepada rekannya. Kata 'amniah' pada tindak tutur tersebut mempunyai makna 'khusus dan rahasia' dan kata 'antum' merupakan bentuk jamak dari kata ganti (dhamir) 'anta' yang bermakna 'kamu (laki-laki)'. Kata 'antum' mempunyai makna 'kamu-kamu (laki-laki) sekalian'. Kata 'antum' pada konteks pembicaraan tersebut di atas bermakna 'kamu atau Anda', yang sengaja dipergunakan untuk maksud menghormati lawan tutur.

\section{(5) Antum sudah tafahum dengan staff yang lainnya?}

Tindak tutur tersebut diucapkan pada sebuah situasi ketika seorang aktivis bertanya pada rekan yang lain tentang keadaan staff di organisasi. Kata 'antum' merupakan bentuk jamak dari kata ganti (dhamir) 'anta' yang bermakna 'kamu (laki-laki)'. Kata 'antum' mempunyai makna 'kamu-kamu (laki-laki) sekalian'. Kata 'antum' pada konteks pembicaraan tersebut di atas bermakna 'kamu atau Anda', yang sengaja dipergunakan untuk maksud menghormati lawan tutur. Kata 'tafahum' pada tindak tutur tersebut mempunyai makna 'memahami', dan makna sebenarnya adalah 'kamu (laki-laki) memahami'.

(6) Wah, padahal dua orang itu kan punya fikroh yang beda, ya.

Tindak tutur tersebut diucapkan pada sebuah situasi ketika seorang aktivis membicarakan dua orang yang punya latar belakang dan karakter berbeda tapi bisa menyatu. Kata 'fikroh' pada tindak tutur tersebut mempunyai makna 'pemikiran'.

\section{(7) Sarana tsaqofah kita tidak hanya didapat dalam kajian saja.}


Tindak tutur tersebut diucapkan pada sebuah situasi ketika seorang aktivis sedang menginformasikan sesuatu. Kata 'tsaqofah' pada tindah tutur tersebut mempunya makna 'pengetahuan/kebuadayaan'.

(8) Ada taklimat untuk mengikuti acara yang diadakan kampus.

Tindak tutur tersebut diucapkan pada sebuah situasi ketika seorang aktivis menginformasikan sesuatu kepada khalayak umum. Kata 'taklimat' dalam tindak tutur tersebut mempunyai maksud sebagai sebuah perintah yang disampaikan oleh seseorang yang mempunyai tingkatan di dalam organisasi berada di atas orang-orang yang diberi pengumuman tersebut.

\section{(9) Rihlahnya enaknya kemana, nih?}

Tindak tutur tersebut diucapkan pada sebuah situasi ketika seorang aktivis bertanya tentang rencana bersama satu kelompok. Kata 'rihlah' pada tindak tutur tersebut mempunyai makna 'rekreasi/tamasya'.

(10) Maklum, akh. Akhir-akhir ini dia sedang futur.

Tindak tutur tersebut diucapkan pada sebuah situasi ketika seorang aktivis menyampaikan keadaan seseorang yang dikenalnya pada teman yang lainnya. Kata 'futur' sebenarnya mempunyai makna 'pembawaan sejak lahir', akan tetapi pada tindak tutur di atas mempunyai makna 'penurunan' sehingga makna yang dimaksud adalah 'sedang mengalami penurunan dalam hal ibadah'.

(11) Jika ada orang yang tidak suka dengan penampilan kita, semua itu sudah menjadi sunnatullah.

Tindak tutur tersebut diucapkan pada sebuah situasi ketika seorang aktivis menginformasikan sesuatu kepada teman yang lain. Frase 'sunnatullah' mempunyai makna 'sudah menjadi ketentuan Allah' dan makna dalam tindak tutur tersebut kemudian menjadi 'segala hal yang sudah semestinya terjadi di dunia ini'.

(12) Berapa banyak harokah islamiyah yang sekarang ada, kita juga harus tahu dan sebagai dirosah juga.

Tindak tutur tersebut diucapkan pada sebuah situasi ketika seorang aktivis menginformasikan sesuatu kepada teman yang lain. Frase 'harokah islamiyyah' pada tindak tutur di atas mempunyai makna 'aliran-aliran dalam agama Islam' dan kata 'dirosah' mempunyai makna 'pelajaran atau pengetahuan'.

\section{(13) Siapa yang mau walimahan, kalau boleh ane ikutan ya, soalnya ane nggak punya barengan.}

Tindak tutur tersebut diucapkan pada sebuah situasi ketika seorang aktivis bertanya sesuatu kepada temannya yang lain. Kata 'walimahan' pada tindak tutur di atas sebenarnya berasal dari bahasa Arab 'walimah' yang bermakna 'pesta/resepsi' dan kemudian diberi imbuhan -an. Kata 'walimahan' tersebut menjadi mempunyai makna baru yaitu 'mendatangi resepsi pernikahan'. Dan kata 'ane' pada konteks pembicaraan tersebut di atas, sebenarnya berasal dari kata 'ana' dalam bahasa Arab yang bermakna 'saya'. Kata 'ane' yang mengacu pada kata 'ana' sebenarnya 
terilhami oleh dialek Betawi, yang kemudian banyak dituturkan oleh orang-orang di luar penutur dialek Betawi.

(14) Antum jangan su'udzon dulu, ditabayunkan dulu sama yang bersangkutan. Tindak tutur tersebut diucapkan pada sebuah situasi ketika seorang aktivis menyarankan sesuatu kepada temannya. Kata 'antum' merupakan bentuk jamak dari kata ganti (dhamir) 'anta' yang bermakna 'kamu (laki-laki)'. Kata 'antum' mempunyai makna 'kamu-kamu (laki-laki) sekalian'. Kata 'antum' pada konteks pembicaraan tersebut di atas bermakna 'kamu atau Anda', yang sengaja dipergunakan untuk maksud menghormati lawan tutur. Kata 'su'udzon' mempunyai makna 'berprasangka buruk'. Dan kata 'ditabayunkan' berasal dari bahasa Arab 'tabayun' bermakna 'penjelasan/konfirmasi' yang kemudian bercampur kode dan mendapat imbuhan 'di-/-kan'.

(15) Jangan lupa, sore ini ada kajian dari departemen annisa.

Tindak tutur tersebut diucapkan pada sebuah situasi ketika seorang aktivis menginformasikan sesuatu kepada temannya. Kata 'annisa' pada tindak tutur tersebut mempunyai makna 'wanita atau perempuan'.

\section{d. Tindak Tutur Direktif}

Tindak tutur direktif kadang-kadang disebut juga tindak tutur impisiotif yaitu tindak tutur yang dilakukan penuturnya dengan maksud agar si pendengar melakukan tindakan yang disebutkan didalam ujaran itu (Gunarwan, 1992 : 11). Tindak tutur direktif dimaksudkan untuk menimbulkan beberapa efek melalui tindakan sang penyimak (Tarigan, 1990 : 47). Yang termasuk dalam jenis tindak tutur direktif ini adalah tuturan memaksa, mengajak, meminta, menyuruh, menagih, mendesak, memohon, menyarankan, memerintah, memberi aba-aba, menentang (Rustono, 1999 : 48).

(1) Kita harus menjadi generasi robbani yang selalu ta'at.

Tindak tutur tersebut diucapkan pada sebuah situasi ketika seorang aktivis mengingatkan kepada teman-temannya tentang sesuatu. Kata 'robbani' pada tindak tutur tersebut mempunyai maksud 'berada di jalan Allah'.

(2) Ketika ada seruan, maka kita wajib "sami'na wa atha'na".

Tindak tutur tersebut diucapkan pada sebuah situasi ketika seorang aktivis mengingatkan kepada teman-temannya tentang sesuatu. Frase 'sami'na wa atha'na' pada tindak tutur tersebut mempunyai makna 'kami mendengarkan dan kami menaatinya'.

\section{(3) Mari kita awali majlis kita dengan membaca basmalah bersama-sama.}

Tindak tutur tersebut diucapkan pada sebuah situasi ketika seorang aktivis mengingatkan kepada teman-temannya tentang sesuatu. Kata 'majlis' pada tindak tutur di atas sudah diadaptasi dalam bahasa Indonesia menjadi 'majelis' yang mempunyai makna sama yaitu 'majelis'. Kata 'basmallah' mengacu kepada 'doa yang diucapkan sebelum memulai mengerjakan sesuatu' yaitu bismillaahirrahmaanirrahiimi'. 
(4) Untuk pekan besok tetep ada tugas, sebelumnya kita tutup majlis ini dengan membaca hamdalah, istighfar dan doa kafarotul majlis.

Tindak tutur tersebut diucapkan pada sebuah situasi ketika seorang aktivis mengingatkan kepada teman-temannya tentang sesuatu. Kata 'majlis' pada tindak tutur di atas sudah diadaptasi dalam bahasa Indonesia menjadi 'majelis' yang mempunyai makna sama yaitu 'majelis'. Kata 'hamdallah' mengacu pada 'doa yang diucapkan sebagai wujud syukur kepada Allah' yaitu ucapan 'alhamdulillaahirrabbil'alamiin'. Kata 'istighfar' bermakna 'meminta ampun atau maaf' mengacu pada 'doa yang diucapkan sebagai bentuk permohonan ampun atau maaf kepada Allah' yaitu ucapan 'astaghfirullaahal'adziim'. Frase 'doa kafarotul majlis' mengacu kepada 'doa yang diucapkan untuk menutup dan mengakhiri sebuah forum-forum majelis'.

(5) Sesama teman se-amanah itu harus saling tafahum.

Tindak tutur tersebut diucapkan pada sebuah situasi ketika seorang aktivis mengingatkan kepada teman-temannya tentang sesuatu. Kata 'amanah' mempunyai makna asli yaitu 'kepercayaan/keyakinan', akan tetapi pada tindak tutur tersebut mempunyai makna 'satu departemen dalam organisasi'. Dan kata 'tafahum' pada tindak tutur tersebut mempunyai makna 'memahami', dan makna sebenarnya adalah 'kamu (laki-laki) memahami'.

\section{(6) Kita menjadi jundi-jundi yang siap maju di jalan jihad.}

Tindak tutur tersebut diucapkan pada sebuah situasi ketika seorang aktivis mengingatkan kepada teman-temannya tentang sesuatu. Kata 'jundi' mempunyai makna asli 'tentara' dan jika dalam bentuk jamak menjadi 'junuud' yang bermakna 'tentara-tentara'. Akan tetapi pada tindak tutur tersebut kata 'jundi' agar bermakna jamak menjadi 'tentara-tentara' maka kata tersebut diulang sesuai kaidah tata bahasa Indonesia. Tindak tutur ini merupakan salah satu bentuk interferensi bahasa Arab yang masuk dalam bahasa Indonesia. Sedangkan kata 'jihad' mempunyai makna 'berjuang'.

\section{e. Tindak Tutur Komisif}

Tindak tutur komisif melibatkan pembicara pada beberapa tindakan yang akan datang seperti menjanjikan, bersumpah, menawarkan, dan memanjatkan doa (Tarigan, 1990 : 47). Tindak tutur komisif merupakan tindak tutur yang berfungsi mendorong pembicara melakukan sesuatu seperti menyatakan kesanggupan. Jenis tindak komisif ini jarang sekali digunakan karena tindak komisif merupakan suatu tindakan janji yang harus ditepati.

(1) Syafakillah ya, semoga diberikan kemudahan dan kesembuhan.

Tindak tutur tersebut diucapkan pada sebuah situasi ketika seorang aktivis mendoakan temannya yang sedang sakit. Frase 'syafakillaah' pada tindak tutur tersebut mempunyai maksud 'semoga Allah memberi kesembuhan'.

\section{(2) Met milad saudariku, semoga selalu istiqomah dan sukses.}

Tindak tutur tersebut diucapkan pada sebuah situasi ketika seorang aktivis mendoakan temannya yang sedang berulang tahun. Kata 'milad' pada tindak tutur di 
atas mempunyai makna 'ulang tahun' dan kata 'istiqomah' mempunyai makna 'konsisten'.

(3) Barakallaah ya, dagangan di departemen antum laku semua.

Tindak tutur tersebut diucapkan pada sebuah situasi ketika seorang aktivis mendoakan temannya yang sedang berbahagia. Frase 'barakallaah' pada tindak tutur tersebut mempunyai maksud 'semoga Allah memberkahi'. Dan kata 'antum' merupakan bentuk jamak dari kata ganti (dhamir) ' $a n t a '$ yang bermakna 'kamu (lakilaki)'. Kata 'antum' mempunyai makna 'kamu-kamu (laki-laki) sekalian'. Kata 'antum' pada konteks pembicaraan tersebut di atas bermakna 'kamu atau Anda', yang sengaja dipergunakan untuk maksud menghormati lawan tutur.

\section{f. Tindak Tutur Ekspresif dan Deklaratif}

Tindak tutur ekspresif yaitu tindak tutur yang mendorong penutur melakukan sesuatu seperti bersumpah berjanji (Suyono, 1996 : 5). Tindak tutur deklarasi adalah tindak tutur yang dilakukan si penutur dengan maksud untuk menciptakan hal (status, keadaan dan sebagainya) yang baru (Gunarwan, 1992 : 12). Tuturan-tuturan dengan maksud mengesahkan, memutuskan, membatalkan, melarang, mengijinkan, mengangkat, menggolongkan, mengampuni dan memaafkan termasuk kedalam tindak tutur deklaratif. Kedua macam tindak tutur ini tidak ditemukan dalam pertuturan di kalangan aktivis pergerakan Islam kampus.

\section{Motivasi Penggunaan Istilah berbahasa Arab dalam Berkomunikasi pada Komunitas Pergerakan Islam}

Angket dipergunakan untuk mengumpulkan data tentang motivasi dan konteks penggunaan istilah berbahasa Arab dalam berkomunikasi pada komunitas pergerakan Islam. Pada saat penelitian ini berlangsung, peneliti membagikan 150 angket kepada calon responden, dan hanya 95 angket yang bisa ditarik kembali. Adapun hasil angket dan pembahasannya adalah sebagai berikut.

Pada point pertanyaan tertang bahasa yang dipergunakan dalam berkomunikasi atau percakapan sehari-hari oleh komunitas pergerakan Islam mendapatkan respon sebanyak 30 orang $\mathbf{3 1 \%}$ ) responden mempergunakan bahasa daerah (dalam hal ini bahasa Jawa) untuk berkomunikasi sehari-hari. Sebanyak 30 orang (32\%) responden mempergunakan bahasa Indonesia untuk berkomunikasi sehari-hari. 19 orang (20\%) responden mempergunakan bahasa asing (bisa bahasa Inggris atau bahasa Arab) dalam berkomunikasi sehari-hari, dan sebanyak 16 orang (17\%) responden melakukan campur kode (mencampur beberapa bahasa - bahasa Indonesia, bahasa Jawa, dan bahasa Arab) dalam berkomunikasi setiap harinya. Prosentase terlihat pada diagram berikut.

Diagram 1. Prosentase bahasa yang dipergunakan dalam komunikasi sehari-hari 


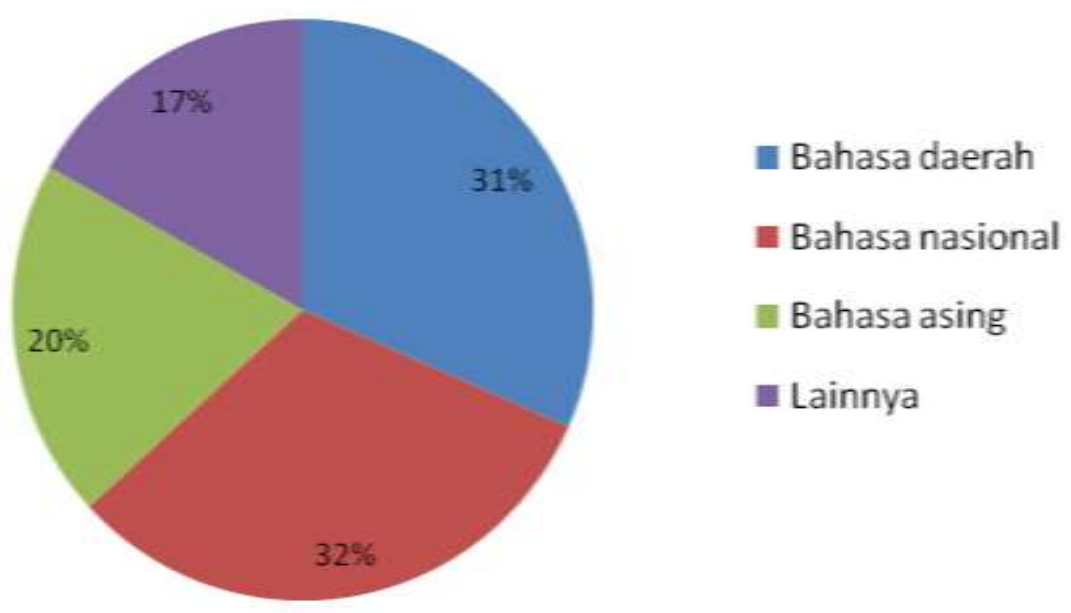

Untuk pertanyaan tentang bahasa yang dipergunakan untuk berkomunikasi oleh komunitas pergerakan Islam saat bertemu, berkumpul, dan beraktivitas bersama sesama aktivis pergerakan Islam atau unit-unit kerohanian Islam kampus, mendapatkan respon sebanyak 20 orang (21\%) responden mempergunakan bahasa daerah saat berkomunikasi. Sebanyak 38 orang (40\%) responden mempergunakan bahasa Indonesia saat berkomunikasi. 19 orang $\mathbf{( 2 0 \% )}$ responden mengungkapkan bahwa mereka mempergunakan bahasa asing (bahasa bahasa Arab) saat berkomunikasi. Dan sebanyak 18 orang (19\%) responden mengungkapkan bahwa mereka melakukan campur kode (mencampur beberapa bahasa - bahasa Indonesia, bahasa Jawa, dan bahasa Arab) saat berkomunikasi dengan sesama anggota pergerakan Islam. Prosentase tersebut terlihat pada diagram berikut.

\section{Diagram 2. Prosentase bahasa yang dipergunakan dalam komunikasi dengan sesama anggota pergerakan Islam}

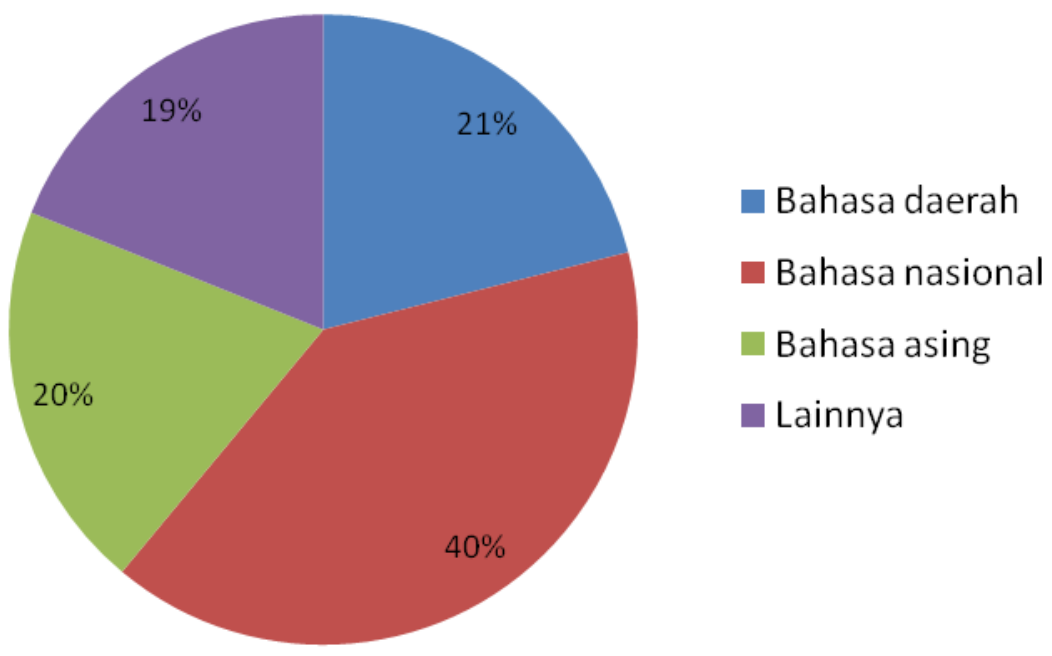

Pada pertanyaan tentang kecenderungan para aktivis pergerakan Islam atau unitunit kerohanian Islam kampus untuk menyisipkan kata-kata atau istilah berbahasa Arab 
dalam komunikasi lisan saat bertemu, berkumpul, dan beraktivitas bersama sesama aktivis pergerakan Islam atau unit-unit kerohanian Islam kampus, mendapatkan respon sebanyak 54 orang (57\%) responden mengiyakan kecenderungan tersebut, dan sebanyak 40 orang $(\mathbf{4 3 \%})$ menyatakan bahwa tidak mengikuti kecenderungan tersebut karena tidak bisa dan tidak memahami bahasa Arab. Adapun alasan responden yang mengiyakan kecenderungan tersebut adalah sebanyak 9 orang (16\%) responden menyatakan alasan untuk membumikan bahasa Arab sbg bahasa Alquran dan bahasa ahli syurga. 9 orang (17\%) responden menyatakan alasan bahwa untuk menunjukkan karakter aktivis pergerakan Islam. 8 orang $(\mathbf{1 5 \%})$ responden menyatakan alasan untuk mengikuti tren yang berkembang di kalangan aktivis pergerakan Islam. 8 orang (15\%) responden menyatakan alasan umtuk membudayakan bahasa Arab sebagai bahasa yang identik dengan orang Islam. 7 orang $\mathbf{( 1 3 \% )}$ responden menyatakan alasan sebagai salah satu upaya dakwah keislaman. 7 orang (13\%) responden menyatakan alasan melakukan campur kode hanya ikut-ikutan teman sesama aktivis pergerakan Islam, dan 6 orang (11\%) responden menyatakan alasan bahwa melakukan campur kode hanya sebagai kebiasaan saja. Presentase tersebut dapat dilihat pada diagram berikut.

\section{Diagram 3. Prosentase kecenderungan campur kode dalam komunikasi dengan sesama anggota pergerakan Islam}
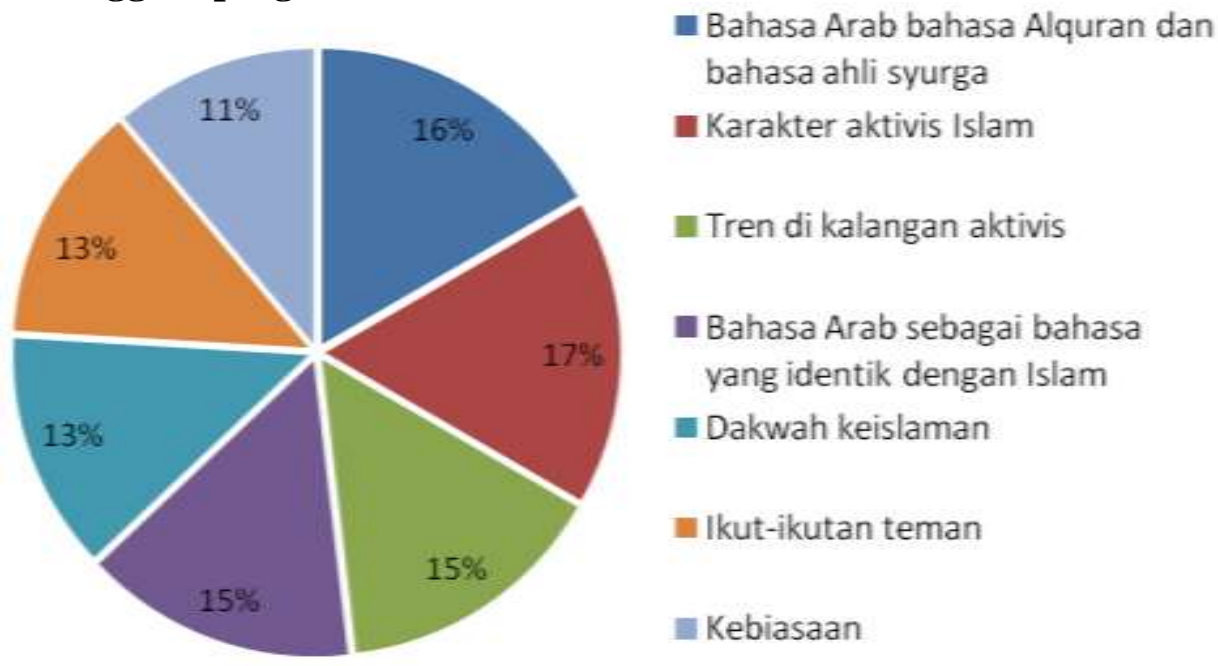

Bahasa Arab bahasa Alquran dan bahasa ahli syurga

Karakter aktivis Islam

Tren di kalangan aktivis

Bahasa Arab sebagai bahasa yang identik dengan Islam

- Dakwah keislaman

Ikut-ikutan teman

Kebiasaan

Pertanyaan tentang tujuan atau motivasi para aktivis pergerakan Islam saat menyisipkan kata atau istilah berbahasa Arab ketika berkomunikasi dengan sesama aktivis unit kerohanian Islam kampus, mendapat respon sebanyak 28 orang (29\%) responden menyatakan mempunyai motivasi untuk menunjukkan identitas sebagai seorang muslim. 23 orang (24\%) responden menyatakan mempunyai motivasi untuk menunjukkan ketertarikan pada bahasa Arab. 29 orang (31\%) responden mempunyai motivasi sebagai sarana pendukung kegiatan dakwah, dan sebanyak 15 orang (16\%) responden mempunyai motivasi agar terlihat keren dan bergaya. Presentase tersebut dapat dilihat pada diagram berikut.

Diagram 4. Prosentase kecenderungan campur kode dalam komunikasi dengan sesama anggota pergerakan Islam 


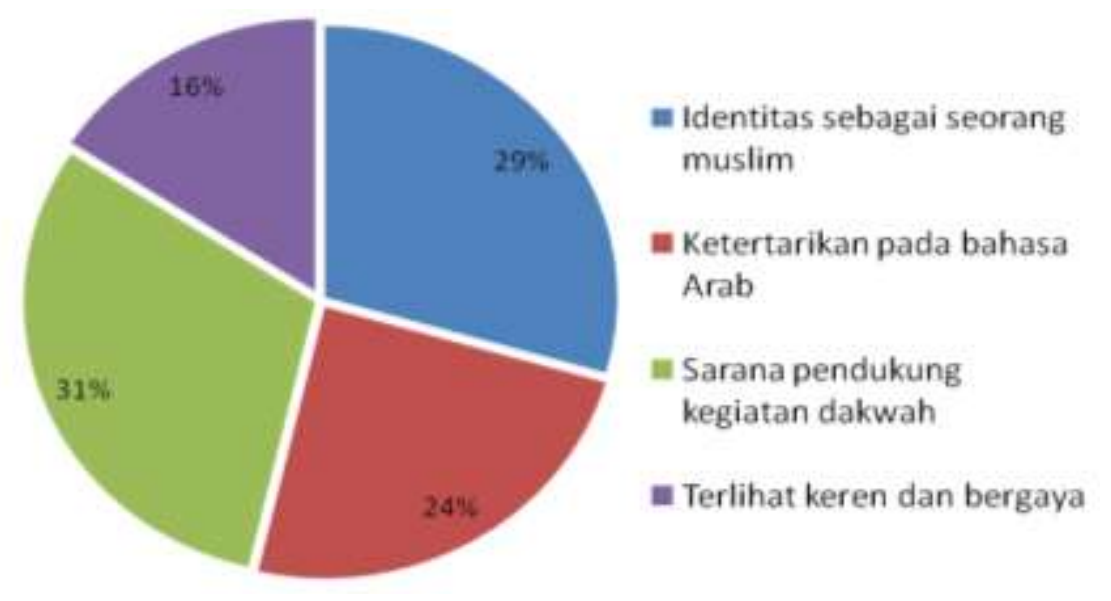

Pertanyaan tentang kebanggaan yang muncul dalam diri para aktivis pergerakan Islam saat menyisipkan kata atau istilah berbahasa Arab ketika berkomunikasi, mendapatkan respon sebanyak 54 orang $(\mathbf{5 7 \%})$ responden menyatakan ada kebanggaan dalam diri mereka saat menyisipkan kata atau istilah berbahasa Arab ketika berkomunikasi. Dan sebanyak 41 orang (43\%) responden menyatakan tidak ada kebanggaan, dan menganggap hal tersebut sebagai kewajaran dan kebiasaan saja.

Adapun alasan yang dikemukakan oleh 54 orang (57\%) responden adalah bahwa sebanyak 11 orang (20\%) responden menyatakan kebanggaan sebagai muslim yang berbahasa Arab. 11 orang $\mathbf{( 2 0 \% )}$ responden menyatakan kebanggaan karena bisa menambah khazanah pengetahuan bahasa asing baru yaitu bahasa Arab. 10 orang (19\%) responden menyatakan kebanggan karena dengan menyisipkan kata atau istilah berbahasa Arab ketika berkomunikasi dapat menambah pengalaman dalam berdakwah. 9 orang $(\mathbf{1 7 \%})$ responden menyatakan kebanggan menyisipkan kata atau istilah berbahasa Arab ketika berkomunikasi karena bahasa Arab adalah bahasa persaudaraan. 7 orang $\mathbf{( 1 3 \% )}$ responden menyatakan kebanggan menyisipkan kata atau istilah berbahasa Arab ketika berkomunikasi karena bahasa Arab sebagai bahasa Al Qur'an dan bahasa internasional. Dan 6 orang (11\%) responden menyatakan kebanggan menyisipkan kata atau istilah berbahasa Arab ketika berkomunikasi karena biar tidak malu dengan sesama aktivis pergerakan Islam lainnya. Presentase tersebut dapat dilihat pada diagram berikut.

Diagram 5. Prosentase alasan kebanggaan melakukan campur kode dalam komunikasi dengan sesama anggota pergerakan Islam 


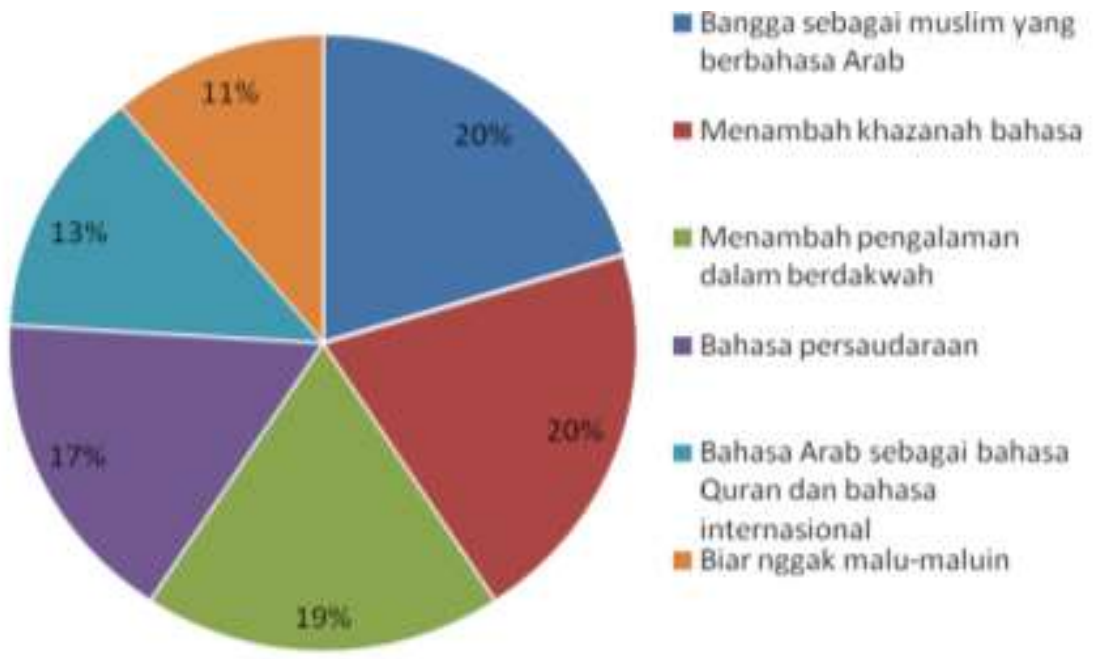

Pertanyaan tentang keseringan para aktivis unit kerohanian Islam kampus menyisipkan kata-kata atau istilah berbahasa Arab setiap berkomunikasi dengan sesama aktivis, mendapatkan respon sebanyak 35 orang (37\%) responden menyatakan sering menyisipkan kata-kata atau istilah berbahasa Arab setiap berkomunikasi dengan sesama aktivis. 18 orang (19\%) responden menyatakan selalu menyisipkan kata-kata atau istilah berbahasa Arab setiap berkomunikasi dengan sesama aktivis. 21 orang (22\%) responden menyatakan jarang sekali menyisipkan kata-kata atau istilah berbahasa Arab setiap berkomunikasi dengan sesama aktivis. Dan 20 orang $\mathbf{2 1 \% )}$ responden menyatakan hanya kadang-kadang saja menyisipkan kata-kata atau istilah berbahasa Arab setiap berkomunikasi dengan sesama aktivis. Presentase tersebut dapat dilihat pada diagram berikut.

Diagram 6. Prosentase keseringan para aktivis unit kerohanian Islam kampus menyisipkan kata-kata atau istilah berbahasa Arab setiap berkomunikasi dengan sesama aktivis

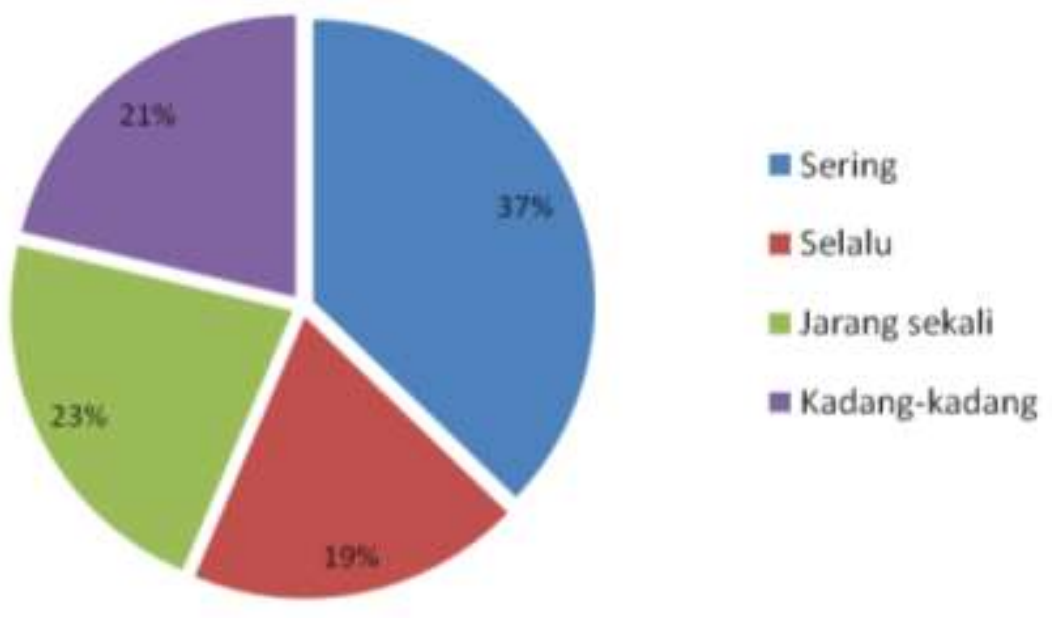

Pertanyaan tentang penggunaan kata-kata atau istilah berbahasa Arab dalam setiap berkomunikasi meskipun tidak dengan sesama aktivis unit kerohanian Islam kampus, mendapatkan respon sebanyak 43 orang (46\%) responden menggunakan katakata atau istilah berbahasa Arab dalam setiap berkomunikasi dengan siapa saja. Komunikasi tersebut bisa dengan dosen, keluarga, teman satu kost, dan sebagainya. Dan 
sebanyak 51 orang (54\%) responden menggunakan kata-kata atau istilah berbahasa Arab saat berkomunikasi dengan sesama aktivis unit kerohanian Islam kampus saja.

Adapun alasan yang diungkapkan oleh 51 orang responden tersebut adalah sebanyak 15 orang (29\%) responden khusus menggunakan kata-kata atau istilah berbahasa Arab saat berkomunikasi dengan sesama aktivis unit kerohanian Islam kampus saja untuk memperlancar kegiatan dakwah Islam. 16 orang (31\%) responden khusus menggunakan kata-kata atau istilah berbahasa Arab saat berkomunikasi dengan sesama aktivis unit kerohanian Islam kampus saja karena lebih paham bahasa Arab sehingga komunikasi menjadi lancar. 11 orang $(\mathbf{2 2 \%})$ responden khusus menggunakan kata-kata atau istilah berbahasa Arab saat berkomunikasi dengan sesama aktivis unit kerohanian Islam kampus saja karena tidak semua orang bisa berbahasa Arab. Dan sebanyak 9 orang (18\%) responden khusus menggunakan kata-kata atau istilah berbahasa Arab saat berkomunikasi dengan sesama aktivis unit kerohanian Islam kampus saja agar tidak terlihat eksklusif dan tidak untuk bergaya. Presentase tersebut dapat dilihat pada diagram berikut.

Diagram 7. Prosentase rekan tutur dalam penggunaan kata-kata atau istilah berbahasa Arab dalam setiap berkomunikasi

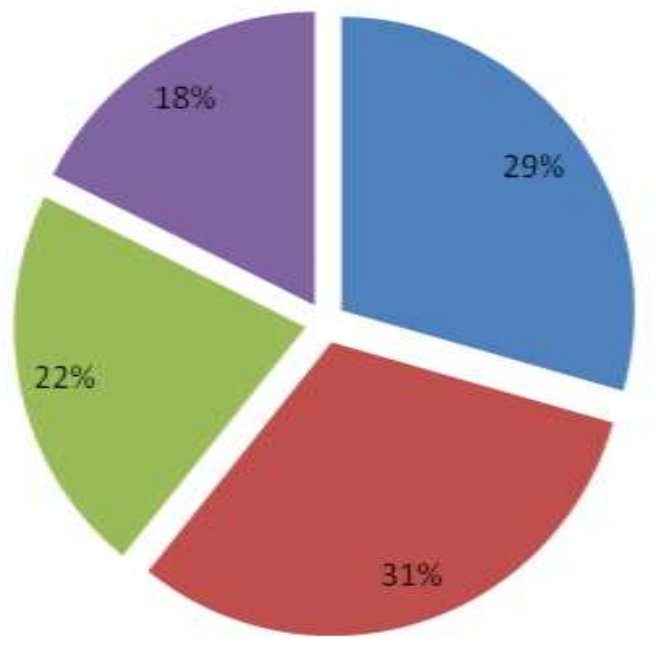

Kegiatan dakwah Islam

Sesama aktivis karena lebih paham

Tidak semua orang bisa bahasa Arab

Agar tidak terlihat eksklusif dan sok-sokan

Pertanyaan tentang pemahaman para aktivis unit kerohanian Islam kampus tentang makna atau arti sebenarnya dari kata-kata atau istilah berbahasa Arab yang dipergunakan dalam berkomunikasi, mendapatkan respon sebanyak 37 orang (39\%) responden menyatakan mengetahui makna atau arti sebenarnya dari kata-kata atau istilah berbahasa Arab tersebut. 18 orang (19\%) tidak mengetahui makna atau arti sebenarnya dari kata-kata atau istilah berbahasa Arab tersebut. 19 orang (20\%) responden menyatakan asal ikut-ikutan saja sehingga tidak mengetahui makna atau arti sebenarnya dari kata-kata atau istilah berbahasa Arab tersebut. Dan sebanyak 21 orang (22\%) responden menyatakan mengetahui beberapa makna atau arti sebenarnya dari kata-kata atau istilah berbahasa Arab tersebut dan tertarik untuk mencari tahu lebih banyak lagi. Presentase tersebut dapat dilihat pada diagram berikut.

Diagram 8. Prosentase pemahaman para aktivis unit kerohanian Islam kampus tentang makna atau arti sebenarnya dari kata-kata atau istilah berbahasa Arab yang dipergunakan dalam berkomunikasi 


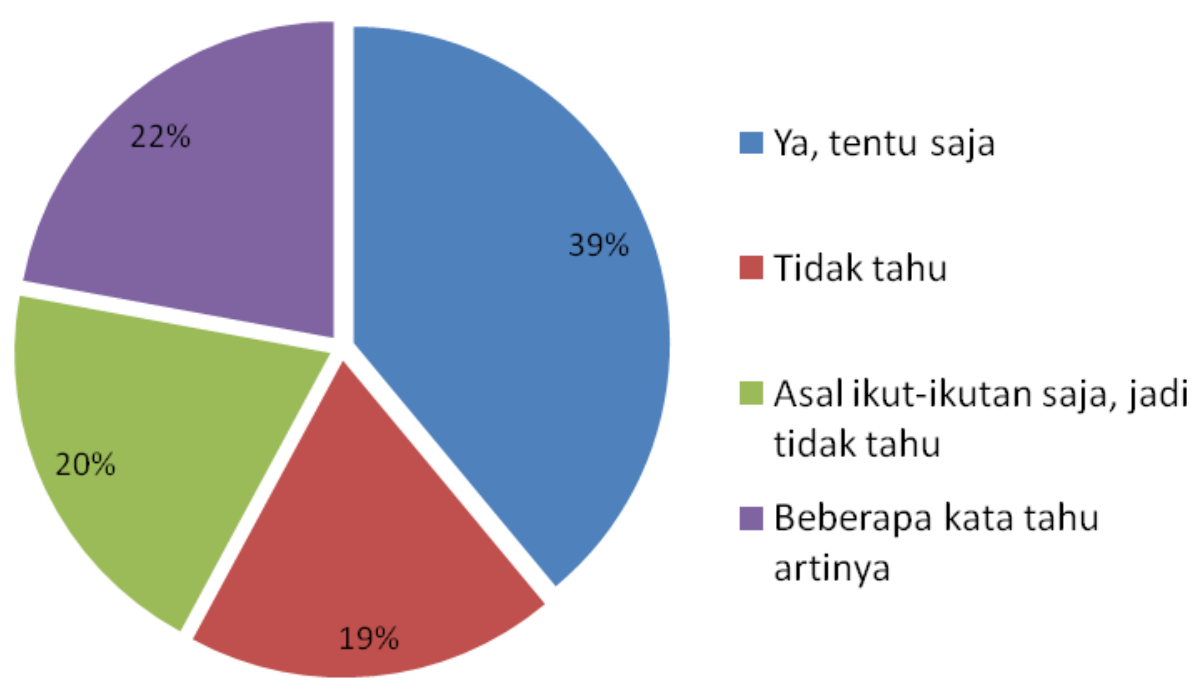

Pertanyaan dari angket yang terakhir, yaitu sumber informasi untuk mengetahui makna atau arti sebenarnya dari kata-kata atau istilah berbahasa Arab, mendapatkan respon sebanyak 32 orang (34\%) responden menyatakan mereka mengetahui makna atau arti sebenarnya dari kata-kata atau istilah berbahasa Arab dari teman sesama aktivis pergerakan Islam. 17 orang (18\%) responden menyatakan mereka mengetahui makna atau arti sebenarnya dari kata-kata atau istilah berbahasa Arab dari teman di luar unit kerohanian Islam kampus. 22 orang $(23 \%)$ responden menyatakan mereka mengetahui makna atau arti sebenarnya dari kata-kata atau istilah berbahasa Arab dari dosen, ustad, dan para kyai. Dan sebanyak 24 orang (25\%) responden menyatakan mereka mengetahui makna atau arti sebenarnya dari kata-kata atau istilah berbahasa Arab dari al Qur'an, buku/novel Islami, dan kamus bahasa Arab. Presentase tersebut dapat dilihat pada diagram berikut.

Diagram 9. Prosentase sumber informasi untuk mengetahui makna atau arti sebenarnya dari kata-kata atau istilah berbahasa Arab

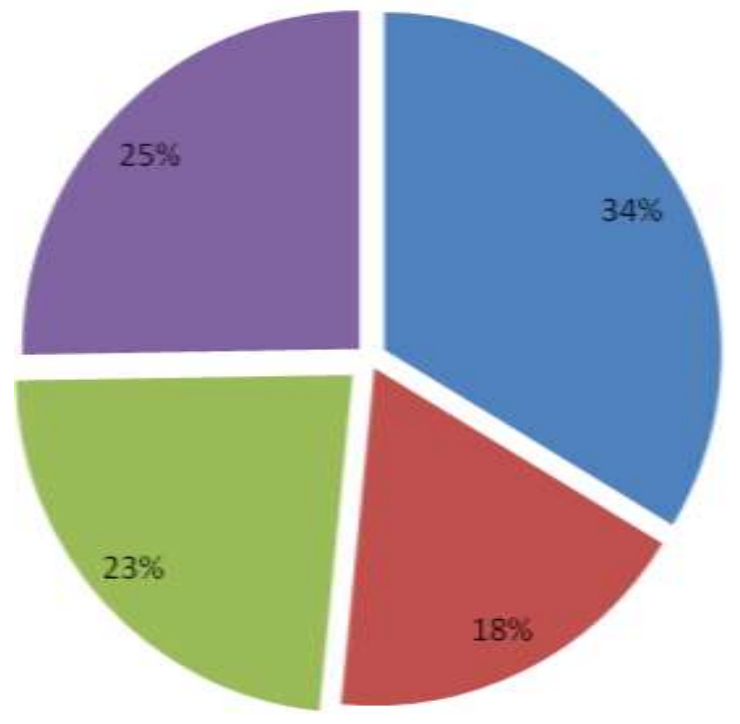

Teman sesama aktivis

Teman di luar unit kerohanian Islam

Dosen, ustad, kyai

- al Qur'an, buku/novel Islami, dan kamus bahasa Arab 


\section{KESIMPULAN}

Berdasarkan penelitian tersebut dapat ditarik kesimpulan sebagai berikut.

1. Ragam dan tindak tutur penggunaan istilah berbahasa Arab pada komunitas pergerakan Islam meliputi tindak tutur lokusi, tindak tutur ilokusi, tindak tutur representatif, tindak tutur komisif, dan tindak tutur direktif ditemukan dalam tindak tutur subjek penelitian.

2. Tindak tutur ekspresif dan tindak tutur deklaratif tidak ditemukan dalam tindak tutur subjek penelitian.

3. Tindak tutur lokusi antara lain (1) Bagaimana baiknya ya apakah kita harus melakukan syuro' dulu? Apa murobbi harus diundang juga? (2) Syuro' itu penting dilakukan dan didiskusikan dengan para murobbi untuk agenda yang mendesak. (3) Ane punya teman yang enak diajak diskusi karena luas banget wawasannya. Walaupun dia bukan ikhwan tapi dia hanif, loh. (4) Sebaik-baiknya kesabaran puncaknya adalah hilm. Maka selalu ana sampaikan dan ingatkan pada antum semua untuk selalu menjaga hilm meski sedang marah sekalipun. Semoga dalam majelis ini dapat menjadi sarana taskiyatun nafs bagi kita. (5) Insya Allah ustadz. Syukron. (6) Seorang akhwat itu harus bisa menjaga izzahnya sebagai seorang muslimah. Seorang muslimah juga harus tekun mempelajari suatu bidang ilmu, makanya kita harus syumul dalam mempelajari suatu bidang ilmu. Salah satu pembelajaran yang efektif adalah melalui talakki yang berkelanjutan. (7) Kemarin ane baru silaturahim ke tempat umahat...bahagia banget kelihatannya. Dan (8) Wah, antum sudah kepengen ya $U k h$.

4. Tindak tutur ilokusi antara lain (1) Jazakillah, Ukhty. Kuenya enak loh. (2) Tafadhol antum baiknya gimana? Nanti kita bawa usulan antum dalam forum syuro besar saja. (3) Jangan lupa minggu depan dimuroja'ah lagi ya, hafalannya. (4) Kita harus waspada akan ghazwul fikr yang dibawa oleh kaum barat. (5) Cari tempat syuro yang ada hijab-nya ya, Ukh. (6) Silakan Pak mas'ul kalau mau menanggapi pendapat ane barusan. (7) Ente ikut dauroh B kan, Akh? (8) Nanti yang baca tasmi' antum ya, Akh?'. (9) Semoga dalam majelis ini dapat menjadi sarana taskiyatun nafs bagi kita. (10) Berkumpulnya kita disini semoga menjadi ghirah bagi masing-masing dari kita. (11) Anti aja ya, yang jadi idarinya. (12) Kalau telat nanti di iqob lho, Ukh. (13) Besok kita riyadloh bareng, yuk!. (14) Antum tsiqah gak kalo ane yang pegang kameranya? Dan (15) Ukhty, bisa minta tolong bantuin ane ngrekap data?.

5. Tindak tutur representatif dalam penelitian ini adalah (1) Besok ada imtihan, materinya apa? (2) Ukhty fillaah, ada i'laan di dengarkan dulu. (3) Kalau yang sirr itu jangan di jaherkan. (4) Ada undangan amniah untuk antum. (5) Antum sudah tafahum dengan staff yang lainnya? (6) Wah, padahal dua orang itu kan punya fikroh yang beda, ya. (7) Sarana tsaqofah kita tidak hanya didapat dalam kajian saja. (8) Ada taklimat untuk mengikuti acara yang diadakan kampus. (9) Rihlahnya enaknya kemana, nih? (10) Maklum, akh. Akhir-akhir ini dia sedang futur. (11) Jika ada orang yang tidak suka dengan penampilan kita, semua itu sudah menjadi sunnatullah. (12) Berapa banyak harokah islamiyah yang sekarang ada, kita juga harus tahu dan sebagai dirosah juga. (13) Siapa yang mau walimahan, kalau boleh ane ikutan ya, soalnya ane nggak punya barengan. (14) Antum jangan su'udzon dulu, ditabayunkan dulu sama yang bersangkutan. Dan (15) Jangan lupa, sore ini ada kajian dari departemen annisa.

6. Angket dipergunakan untuk mengumpulkan data tentang motivasi dan konteks penggunaan istilah berbahasa Arab dalam berkomunikasi pada komunitas pergerakan 
Islam. Pada saat penelitian ini berlangsung, peneliti membagikan 150 angket kepada calon responden, dan hanya 95 angket yang bisa ditarik kembali. 


\section{DAFTAR PUSTAKA}

Bungin, B. 2007. Penelitian Kualitatif. Jakarta: Prenada Media Group.

Chaer, Abdul. 1990. Pembakuan Bahasa Indonesia. Jakarta: Penerbit Rineka Cipta. dan Agustina, Leoni. 2004. Sosiolinguistik: Perkenalan Awal. Jakarta: Penerbit Rineka Cipta.

Creswell, J. W. 1998. Qualitatif Inquiry and Research Design. California: Sage Publications, Inc.

Dick, Kooij JG.1994. Ilmu Bahasa Umum. Penerjemah: TW. Kamil, Penyunting: W.A.L. Stokhof. Jakarta: RUL.

Gunarwan. 1992. Kesantunan Negatif Di Kalangan Dwibahasawan Indonesia-Jawa Di Jakarta : Kajian Sosiopragmatik. Makalah pada Pelba VIII. Jakarta 26-27 Oktober.

Keraf, Goris. 1994. Komposisi. Flores: Penerbit Nusa Indah.

Leech, Geoffarey. 1993. Prinsip-Prinsip Pragmatik. Jakarta:UI Press.

Moleong, J. Lexy. 1995. Metodologi Penelitian Kualitatif. Bandung: Penerbit Remaja Rosdakarya.

Robins, RH. 1995. Sejarah Singkat Linguistik. Terjemahan: Asril Marjohan. Bandung: Penerbit ITB Press.

Rustono. 1999. Pokok-Pokok Pragmatik. Semarang: IKIP Press.

Singarimbun, Masri dan Efendi, Sofian. 1989. Metode Penelitian Survei, Jakarta : Pustaka LP3ES.

Soedjito. 1992. Kosakata Bahasa Indonesia. Jakarta: Penerbit Gramedia.

Sudaryanto. 1993. Metode dan Analisis Bahasa. Yogyakarta: Gadjah Mada University Press.

Suyono. 1990. Pragmatik: Dasar-dasar dan Pengajarannya. Malang: Penerbit YA3

Tarigan, Henry Guntur. 1990. Pengajaran Pragmatik. Bandung: Penerbit Angkasa. 